Economies' Horizons, No. 4(11), pp. 130-135.

DOI: https://doi.org/10.31499/2616$\underline{5236.4(11) .2019 .228705}$

UDC 338.45:658.8:631.3

JEL Classification: C15 E27 M 11

\title{
Formation of the mechanism of competitive pricing for agricultural machinery in Ukraine: current state and prospects
}

\author{
Svetlana M. Marchenko ${ }^{1}$, Cand.Ec.Sc. Associate Professor, \\ Anatoly V. Voropaev ${ }^{2}$, graduate student
}

\begin{abstract}
The purpose of the research. The main purpose of the article is a scientific substantiation of theoretical approaches and practical recommendations related to the formation of competitive pricing for agricultural machinery of domestic production, taking into account the experience of foreign companies. Methodology. To achieve this goal, methods of comparison and synthesis, expert assessments were used. Results. As a result of the study, measures aimed at improving the mechanism of competitive pricing, an increase in the volume of export potential in the agricultural machinery market by quality machines and equipment. In order to increase the export-import potential of agricultural machinery manufacturers, it is advisable to implement a number of measures, namely the support of domestic production of complex agricultural machinery; creation of favorable conditions for constructing concerns and voluntary associations with foreign partners of leading manufacturers of technology in the world; Creation of state support conditions for modernization and technical re-equipment of domestic agricultural manufacturers and the adoption of the law "Buy Ukrainian" in order to support domestic agricultural machinery. Practical meaning. The practical significance of the study is to set out the main provisions, which are brought to the level of specific proposals that can be used by agricultural machinery enterprises in the process of forming a mechanism of competitive pricing of agricultural machinery. The practical significance of the study is to place the basic provisions that are brought to the level of specific proposals that can be used by enterprises of agricultural machine building in the process of improving the mechanism of competitive pricing for agricultural machinery.
\end{abstract}

Keywords: mechanism, competitive pricing, agricultural machinery, pricing policy, market. Number of references: 6; number of tables: 0; number of figures:0; number of formulas: 0 .

\footnotetext{
${ }^{1}$ Interregional Academy of Personnel Management; Educational and Scientific Institute of Management, Economics and Finance; Professor of Marketing; identifierORCID: http://orcid.org/0000-0003-2425-8335; email: arena08@meta.ua

${ }^{2}$ Interregional Academy of Personnel Management; Educational and Scientific Institute of Management, Economics and Finance; graduate student of the Department of Marketing;e-mail: voropaiev1@ gmail.com
} 
Формування механізму конкурентного ціноутворення на сільськогосподарську техніку в Україні: сучасний стан та перспективи

\section{С.М. Марченко ${ }^{1}$, к. е. н., доцент,}

A.B. Воропаєв ${ }^{2}$, аспірант

Анотація. Мета дослідження. Головною метою статті є наукове обгрунтування теоретичних підходів i практичних рекомендацій пов'язаних 3 формуванням конкурентного ціноутворення на сільськогосподарську техніку вітчизняного виробництва $з$ урахуванням досвіду зарубіжних компаній. Методи. Для досягнення поставленої мети було використано методи порівняння і синтезу, експертних оцінок. Результати. У результаті проведеного дослідження запропоновано заходи, спрямовані на удосконалення механізму конкурентного ціноутворення, збільшення обсягу експортного потенціалу на ринку сільськогосподарської техніки якісними машинами та обладнанням. 3 метою підвищення експортно-імпортного потенціалу виробників сільгосптехніки доцільно імплементувати ряд заходів, а саме підтримка вітчизняного виробництва складної сільськогосподарської техніки; створення сприятливих умов для побудови концернів та добровільних об'єднань із зарубіжними партнерами провідних виробників техніки у світі; створення умов державної підтримки щодо модернізації та технічного переоснащення вітчизняних агровиробників та прийняття закону «Купуй українське» 3 метою підтримки вітчизняного сільгоспмашинобудування. Практичне значення дослідження полягає у викладенні основних положень, які доведені до рівня конкретних пропозицій, що можуть бути використані підприємствами сільськогосподарського машинобудування в процесі удосконалення механізму конкурентного ціноутворення на сільськогосподарську техніку.

Ключові слова: механізм, конкурентне ціноутворення, сільськогосподарська техніка, цінова політика, ринок.

1. Introduction. In modern conditions, the preservation of break-even agricultural enterprises is possible only if competitive pricing, namely the ability of enterprises to maintain and strengthen its market positions due to dynamic pricing. The price policy of agricultural enterprises is a major factor in monitoring the changes in market conditions and on the results of its activities.

Formation of a mechanism for competitive pricing for agricultural machinery in Ukraine has its own peculiarities to be taken into account in order to ensure an effective pricing policy of such enterprises as prerequisites for ensuring their competitiveness (Pakhucho, 2018)

Formulation of the problem. In order to increase the efficiency of agricultural machinery enterprises, it is important and relevant to solving the problems of developing theoretical provisions and practical recommendations associated with the formation of a mechanism of competitive pricing for agricultural machinery of domestic production.

2. Literature review. Formation of a mechanism for competitive pricing for agricultural machinery in Ukraine: The current

\footnotetext{
${ }^{1}$ Міжрегіональна Академія управління персоналом; Навчально-науковий інститут менеджменту, економіки та фінансів; професор кафедри маркетингу; iдентифікатор ORCID: http://orcid.org/00000003-2425-8335; e-mail: arena08@meta.ua

${ }^{2}$ Міжрегіональна Академія управління персоналом; Навчально-науковий інститут менеджменту, економіки та фінансів; аспірант кафедри маркетингу; e-mail: voropaiev1@gmail.com
} 
state and prospects of development was investigated by such scientists as: A. Subaeva, A. Nurullin and R. Minnekhanov (2013), O. Zakharchuk (2019), E. Pakhucho (2018), A. Egorshina (2001), G. Podsetsky, M. Gerun and V. Garkava (2013), L. Shkvarchuk (2008).

In general, these authors clearly outlines the problem, but the policy of forming a mechanism for competitive prices for agricultural machinery and the peculiarities of state support are not sufficiently investigated. Particular attention should be paid to the pricing behavior of domestic enterprises in the complex economic conditions of the present.

3. Methods. In order to achieve the goal, research methods were used: analysis and synthesis - to improve existing approaches and clarification of the conceptual apparatus; methods of comparison and synthesis - in the study of peculiarities of pricing on the technique of domestic enterprises of agricultural machinery; The method of expert assessments - in the analysis of factors influencing the formation of a mechanism of competitive pricing of enterprises of agricultural machinery.

4. Research objectives. The main objective consists in the scientific substantiation of theoretical approaches and proposed practical recommendations associated with the formation of a mechanism of competitive pricing for agricultural machinery of domestic production, taking into account the experience of foreign companies.

5. Results and discussions. Formation of pricing policies of agricultural machinery requires a great preliminary work. In the first stage, an analysis of market conditions, its structure, elasticity of demand, etc., is required. The coefficient of elasticity shows how much interest will change the demand for this technique when changing the price of $1 \%$. The price change is the easiest way to accounting for demand, costs, in a competitive struggle. At the second stage, the task of forming a clear strategy of the enterprise in the market is placed, which will ensure not only its survival, but also high income. The basis of the strategy is a pricing policy that uses various pricing methods, namely:

1) charging a small margin for the cost of technology $(10-12 \%)$. This is the simplest method used by virtually all enterprises in a shortage of economy, when demand always exceeds the proposal;

2) large companies with marketing departments, by analyzing different levels of prices and volumes of production choose that option that provides the highest profits;

3) Some firms determine the "price threshold" for the goods close to the price of demand, and provide maximum profit by managing cost. Reducing cost is achieved through new technique, higher labor productivity, etc.;

4) the method of follow-up competitor oriented to current prices is used;

5) an increasing number of firms calculate the price of goods with the provision of discounts and privileges, depending on the conditions and place of its implementation, changes in the weight of the goods or additional service services (Yaciv, Yaciv, (2015).

Pricing, thus, is a complex process that takes into account not only costs, demand and supply, competition, but also many other factors (Subaeva, Nurullin and MineNekhanov, 2013).

For leading concerns a hard competitive struggle and desire to capture new markets. You can distinguish two directions in this process: penetration into new market segments and expansion of existing markets, by mastering additional types of products. In this regard, the Ukrainian market seems very attractive, since the material and technical park of the Ukrainian AIC is severely worn and requiring urgent modernization. The high capacity of the Ukrainian market is a major factor for the work of foreign companies in Ukraine. Competition for domestic agricultural machinery from the largest foreign agricultural machinery manufacturers are a factor that stimulates the development of production and distribution of Ukrainian 
agricultural machinery in the direction of developing new models and a complex of services for its technical and after sales service. Analysis of the Strategies for the Implementation of Foreign Manufacturers on the domestic market will determine the most promising segments of the agricultural machinery market, to identify the basic laws and principles of the work of foreign companies in Ukraine, as well as to develop methods of marketing pricing, taking into account the specifics of Ukrainian conditions. This will contribute to the use of foreign experience in the field of production, distribution and technologies of sales in the Ukrainian agricultural machinery market in order to improve the mechanism of its functioning.

In the market of agricultural machinery, depending on the degree of independence of the enterprise in pricing prices (tariffs) may be free, contractual (contractual) regulated and fixed. Free prices in market conditions are established by the manufacturer of agrarian technology independently, in accordance with the enterprise adopted by price policies; They are formed at the enterprise and approved by his leader. Such prices are established on those types of techniques that are not part of the state list of fixed and regulated prices. The regulator of free prices is only demand and proposal for the technique of defined quality. The state can only indirectly influence the mechanism for forming free prices by changing the market conditions. For example, installing certain "rules of the game" in the market through measures that limit unfair competition and market monopolization. For this purpose, prohibitions on horizontal and vertical fixation of prices, price discrimination, dumping, unscrupulous pricing advertising are introduced (Shkvarchuk, 2008).

A variety of free prices that exist in the agricultural machinery market is the price price and price of the catalog. Pressual prices are used in buying techniques both in the domestic market and in international trade, and are contained in the manufacturers issued by the enterprise (most often manufacturer of technology). They belong to the category of reference prices that are published by the seller. Pressurities of firms (price tags) are information for a non-periodic nature, quite detailed and reliable. Prices of catalog (avenote) are official prices published in catalogs and avenues of firms, enterprises and organizations - distributors of agricultural machinery. They are pricing of a certificate published irregular and, as a rule, the seller of technology. Such prices are used both in the domestic market and in international trade. This price is owned by buyer prices, seller's prices, net prices. The buyer's price is an actual monetary amount of purchase of goods in the market, which is carried out by a purchase and sale agreement or by which the buyer is ready to buy a technique. Formation of a market price as a buyer's price (in the buyer's market) means that the actual price consists of an underestimated level reflecting the buyer's economic interests. The seller's price is formed in a predominance of demand over the proposal (seller's market). This price is an incentive for expanding the production of this product and reflects the economic interests of the seller, which seeks to sell it as possible. Net price does not include discounts and allowances associated with different conditions of supply. This is a clean price of goods in place of his purchase - sales. The net price for the buyer is a sum, actually paid by the seller, and for the seller - actual revenue from the sale of technology, taking into account the costs in connection with the implementation of the agreement (Shkvarchuk, 2008).

Contractual prices are established in the contract between the seller and the buyer with the consent of the parties. Their major differences, from a solid price price price, is that they can change by mutual consent of the parties. Adjustable prices are established by regional pricing authorities operating under the respective executive bodies. Management of pricing policy in the public administration defines for such prices limit levels, excess of 
which is inadmissible. Regulation they carry out pricing bodies in the established upper and lower limits of prices based on price change coefficients by direct restrictions on their growth or decrease, the establishment of boundary prices, marginal deviations from fixed prices, setting the limit of profitability, depending on the marginal size of trading and supply and sales Occupations (margins) in the price of the final realization of some goods, the establishment of the boundary values of the price elements. There are other similar methods of regulation (Shkvarchuk, 2008).

In countries with a developed market economy, state regulation of prices, in certain industries and spheres of the economy, is carried out with the help of support prices. Support prices are established by law and defined by the Government minimum prices, cheaper than the seller of goods or services can not offer them to buyers. The sphere of functioning of support prices are those branches of economics, in which in the long run, the growth rates of market prices for ultimate products of enterprises, as a rule significantly lagging behind the rates of rising prices for material and technical resources that they are purchased from enterprises of other industries. This means that in order to achieve the parity of exchange between industries or the Government approaching it, it is necessary to install on final goods and services of support prices that are higher equilibrium in the market. Such prices allow you to preserve at an acceptable level of parity of prices between enterprises belonging to low-level industries, and enterprises supplying logistical resources for them.

According to scientists of the Institute of Agrarian Economics, in 2021, a negative tendency to reduce export operations will continue. As a result, the further decline in the sales of domestic agrotechnics is projected at $15-20 \%$. The main reason for the decline in the sale of domestic agricultural machinery will be the global economic crisis associated with a pandemic on coronavirus COVID-19, instability in the land resources market and limited access to credit resources.

Export opportunities of Ukraine The main types of agricultural machinery are traditionally significantly lower than imports. However, in 2020, foreign deliveries are critical - by $9.4 \%$ - decreased and amounted to only \$ 37.6 million.

In 2020, the largest decline - almost 2.5 times - exported agricultural tractors. Last year he amounted to $\$ 3.3$ million against $\$ 7.4$ million in 2019. The main importer of this species of domestic agricultural machinery became Belarus. She purchased tractors in Ukraine worth $\$ 1.1$ million - 33.3\% of the total sales value. In second place - Romania, which paid \$ 0.9 million $(27.3 \%)$ for Ukrainian tractors".

Significantly smaller particles in the import of tractors have: Moldova - \$ 0.5 million, $15.2 \%$, Cuba - $\$ 0.4$ million, $12.1 \%$, Israel - \$0.2 million, 6\%. The largest income - \$ 10.3 million - brought domestic manufacturers in 2020 export seeders. However, this figure decreased compared to 2019 by $30 \%$. The largest seeders - 36.9\% acquired Belarus, paying for this type of agricultural machinery $\$ 3.8$ million. Kazakhstan imported seeders worth \$2.7 million (26.2\%), Moldova - \$ 1.3 million (12.6\%), Bulgaria - \$ 1.1 million (10.7\%), and Poland - worth \$ 0.7 million (6.8\%). "The volume of foreign deliveries of mowers decreased compared to 2019 by $9.9 \%$ and accounted for last year $\$ 6.4$ million. The lion's share of mowers purchased Russia, paying \$ 4.2 million $(65.6 \%)$ for them. Kazakhstan purchased this type of agricultural machinery for $\$ 0.8$ million (12.5\%), Moldova - \$ 0.5 million (7.8\%), and Argentina, which for the first time purchased agricultural machinery in Ukraine - by \$ 0.3 million (4, 7\%). Disk harrows brought to the domestic exporters a total of $\$ 2.8$ million. They were exported mainly to: Moldova - $\$ 0.8$ million, $28.6 \%$, Bulgaria - \$ 0.6 million, 21.4\%, Lithuania - \$ 0.3 million, 10, 7\% (Zakharchuk, 2019).

In order to increase export potential, it is necessary to develop and implement a number 
of measures to fill the agricultural machinery market by relevant qualitative competitive machines and equipment, namely: to stimulate their production by domestic machinebuilding enterprises; provide conditions for the creation of joint ventures for agricultural machinery in Ukraine; Provide state support for technical and technological modernization of agrarian production and priorities for the development of domestic agricultural machinery on the production of miniequipment (Zakharchuk, 2019).

The experience of European countries with a developed market economy (France, Germany, Holland, Denmark, etc.) shows that state impact measures can be divided into two groups:

- direct impact of the state on the development of agriculture, which includes the adoption of directive, administrative and planned regulation measures to regulate the industry;

- Indirect influence - price, credit and financial, tax and investment mechanisms (Menedzhment, Marketing I Ekonomika Obrazovaniya, 2001).

It should be noted that the main principles of state regulation should be agrarian protectionism; the unity of legal, economic, social goals.

The basic principles of economic regulation are: taxation, financial and credit policies, antitrust regulation.

However, foreign experience shows that it has long been produced a mechanism for counteracting the growth of the agrarian sector in connection with the rise in price of new technology, fertilizers, fuel and lubricants and other resources.

All countries with a developed market economy spend a significant share of its budgets in support of the agrarian sector, since they depend on their food security, and none of them want to get dependent on the importation of decisive types of food from abroad. Despite the high costs of budget funds, in any of these countries, agriculture is not in a terrible state, and its costs are priority. The market of technology for the needs of the agro-industrial complex is one of the most stable and mature in the segment of special machines. In the Ukrainian market with its enormous capacity, virtually all ruler of domestic and imported techniques is presented. The main theme of interaction between Ukrainian and foreign manufacturers of agricultural machinery is to enter the WTO, which means the reduction of import duties on the products of import marks. First domestic enterprises at the expense of state support managed to hold about $50 \%$ of the market. Now analysts hastened to predict the fall of their own machines up to $15 \%$ by 2020 . But the effect of reducing will be seen from February 2013. During this time, domestic enterprises must decide in which the plane deal with foreign expansion: to reduce prices, exposing the profitability of production, to develop new markets, offer special conditions, based on state support.

Today, the technique of Ukrainian producers meets modern requirements for the technical conditions, the quality of assembly, security, price. And the foreign consumer is ready to buy Ukrainian technicians, but existing financial institutions is not able to compete with foreign banks, since they have a percentage rate as below (Subaeva, Nurullin and MineNekhanov, 2013).

6. Conclusions. Consequently, the reform of pricing on a scientific basis lies in the plane of improving economic relations in the field of production, exchange, distribution and consumption of material goods, on this basis, to solve the problem of effective development of agricultural machinery industry as a whole, it is necessary to revise the structure of the expenditure part of the budget in the direction of increasing the share that It is spent on agriculture, and identify the priority directions of financial and credit support, taking into account the real capabilities of the country's budget.

In order to increase the export-import potential of agricultural machinery manufacturers, it is advisable to implement a number of measures, namely the support of 
domestic production of complex agricultural machinery; creation of favorable conditions for constructing concerns and voluntary associations with foreign partners of leading manufacturers of technology in the world; Creation of state support conditions for modernization and technical re-equipment of domestic agricultural manufacturers and the adoption of the law "Buy Ukrainian" in order to support domestic agricultural machinery. Reforming pricing on a scientific basis lies in the plane of improving economic relations in the field of production, exchange, distribution and consumption of material goods, on this basis, to solve the problem of effective development of agricultural engineering industry as a whole, it is necessary to revise the structure of the expenditure part of the budget in the direction of increasing the share that is spent on Agriculture, and identify the priority directions of financial and credit support, taking into account the real capabilities of the country's budget.

\section{References}

Menedzhment, marketing i ekonomika obrazovaniya (2001), [pod red. A. P. Egorshina], Novgorod: NIMB, $624 \mathrm{p}$.

Metodichni rekomendaciï z obrruntuvannya normativnoï potrebi osnovnih zasobiv na virobnictvo sil's'kogospodars'koï produkciï [G. M. Pidlisec'kij, M. I. Gerun, V. V. Garkavij ta in.], Kyiv, Ukraine, 52 p.

Pakhucha E.V. (2018), Price competition and its impact on the competitiveness of agricultural products. Business Inform. no. 9. P. 117-118, available at: http://www.business-inform.net/pdf/2018/9_0/117_122.pdf/ (Accessed 6 February 2019).

Subaeva A.K., Nurullin A.A., Minnekhanova R.R. (2013)? Assessment of the state of pricing in the market of agricultural machinery [Modern problems of science and education], no.1, available at: https://www.scienceeducation.ru/pdf/2013/1/213.pdf/ (Accessed 6 February 2019).

Oleksandr Zakharchuk "In (2019), exports of agricultural machinery from Ukraine decreased by almost 10.0\%" (2020), posted on the website of the National [Academy of Agrarian Sciences of Ukraine], available at: http://naas.gov.ua/news/?ELEMENT_ID= 5743. (Accessed 6 February 2019).

Shkvarchuk L.O. (2008)? Pricing: textbook [LO Shkvarchuk ], K/ 460p., available at: http://repository.ldufk.edu.ua/handle/34606048/21237. (Accessed 6 February 2019). 